http://dx.doi.org/10.18778/1509-877X.03.02

\title{
KONTROWERSJE WOKÓŁ TZW. USZCZELNIANIA SYSTEMU PODATKOWEGO W KONTEKŚCIE OSTATNICH ZMIAN ODNOSZĄCYCH SIĘ DO PODATKU OD TOWARÓW I USŁUG
}

\begin{abstract}
Streszczenie. Przedmiotem rozważań jest analiza dokonanych wybranych zmian, które zwykło się powszechnie nazywać „uszczelnianiem systemu podatkowego”. Jest to reakcja na te zachowania obrotu prawno-gospodarczego, które można kwalifikować jako nadużycia systemu podatkowego. Artykuł stanowi zestawienie najistotniejszych w ocenie autora możliwych środków reakcji prawnej na zaistnienie w obrocie zdarzeń, których konsekwencją jest naruszenie lub zagrożenie naruszenia interesów finansowych państwa, w tym w szczególności wystąpienie zjawiska określanego normatywnie w dogmatyce prawa karnego jako uszczuplenie podatków. W artykule poruszona zostanie problematyka możliwych sposobów przeciwdziałania „nieszczelności” w systemie podatkowym, ze wskazaniem mechanizmów właściwych dla konstrukcji prawnej i specyfiki podatku od towarów i usług. Istniejące regulacje prawne nie są wystarczające, aby uniknąć występowania nadużyć fiskalnych, konstrukcja samego podatku i zasady ustalania stawek są źródłem występujących zagrożeń, oczekiwania jakie UE i państwa członkowskie pokładają w podatku od wartości dodanej nie są spełnione.
\end{abstract}

Słowa kluczowe: podatek od towarów i usług, split payment, mechanizm podzielonej płatności, system teleinformatyczny, STIR, Jednolity Plik Kontrolny, rachunek VAT, mechanizm odwróconego obciążenia VAT, „uszczelnianie”, „luka podatkowa”.

* Dr hab., Katedra Prawa Finansowego, Wydział Prawa, Administracji i Ekonomii, Uniwersytet Wrocławski. 
Wyzwania związane z unikaniem opodatkowania, agresywnym planowaniem podatkowym i szkodliwą konkurencją podatkową stały się ostatnio tematem kluczowej wagi.

Podatek od wartości dodanej w kształcie, jaki obecnie występuje w UE jest organizacyjnie skomplikowany, prawnie mało przejrzysty, kosztowny w obsłudze oraz poprzez występowanie wielu „luk” prawnych i rozbieżności interpretacyjnych regulacji prawnych narażony na nadużycia fiskalne ${ }^{1}$. Istniejące regulacje prawne nie są wystarczające, aby uniknąć występowania nadużyć fiskalnych, konstrukcja samego podatku i zasady ustalania stawek są źródłem występujących zagrożeń, oczekiwania jakie UE i państwa członkowskie pokładają w podatku od wartości dodanej nie są spełnione. Firma audytorska PricewaterhouseCoopers (PWC) w swoim raporcie ${ }^{2}$ wskazała, że podatek od wartości dodanej generuje największe zagrożenie działalnością przestępczą.

Sytuacja, w której istniejące podatkowe uregulowania prawne prowadzą w konsekwencji do innych niż zamierzone przez legislatora celów, czyli nie spełniają lub nie spełniają w pełnym zakresie dedykowanych funkcji czy zadań, może być podstawą do uznana przedmiotowych regulacji prawnych za dysfunkcjonalne. Zgodnie ze Słownikiem Jezzyka Polskiego ${ }^{3}$, dysfunkcjonalny oznacza: nieprzystosowany lub nieprawidłowo dostosowany do pełnienia określonych funkcji, zadań, celów, oczekiwań; niefunkcjonalny; dysfunkcyjny.

Dogmatyka prawa nie konstruuje pojęcia „szczelnego” systemu podatkowego. Jest to sformułowanie języka potocznego, pozaprawna kategoria opisu systemu podatkowego. Prawną kategorią opisu systemu finansowego jest natomiast pojęcie efektywności, na co wskazuje ustawodawca chociażby w art. 68 ust. 1 ustawy z dnia 27 sierpnia 2009 r. o finansach publicznych ${ }^{4}$. Dyspozycja normy odkodowanej z treści tego przepisu stanowi o powinności realizacji celów i zadań publicznych - w tym w zakresie

${ }^{1}$ J. Pastuszka, Dysfunkcjonalność ekonomiczna podatku od wartości dodanej $w$ transakcjach wewnątrzwspólnotowych Unii Europejskiej, Radom 2013, s. 23.

${ }^{2}$ Raport PricewaterhouseCoopers PwC, Straty Skarbu Państwa w VAT - luka podatkowa, oszustwa, wyłudzenia oraz problematyka podatku od towarów i usług w Polsce, 2013.

${ }^{3}$ http://sjp.pwn.pl/szukaj/dysfunkcjonalny.html [dostęp: 12.04.2017].

${ }^{4}$ Ustawa z dnia 27 sierpnia 2009 r. o finansach publicznych (Dz.U. z 2017 r., poz. 2077). 
gromadzenia środków pieniężnych - w sposób zgodny z prawem, oszczędny, terminowy i efektywny.

Należy przyjąć, że „szczelność” jest to pewna subkategoria pojęciowa w ramach szerszego pojęcia efektywności. Efektywność bowiem rozpatrywać można w dwóch aspektach ${ }^{5}$ : primo - jako efektywność organizacyjną (organizational effectiveness), która wyraża ujęcie jakościowe, secundo - jako wydajność (organizational performance), która przyjmuje rozumowanie ilościowe. Jakościowe ujęcie efektywności skoncentrowane jest bowiem na realizacji założonych celów - tymi celami w organizacji systemu danin publicznych są cele fiskalne i społeczno-gospodarcze. Efektywność w ujęciu ilościowym z kolei zorientowana jest na mierzalne wyniki działań względem nakładów - koncentruje się zatem na osiągniętych wpływach środków pieniężnych do budżetu państwa przy określonym zorganizowaniu systemu gromadzenia dochodów. Kategoria „szczelności” nosi zatem desygnaty pojęcia wydajności w wyżej wskazanym znaczeniu, ponieważ odnosi się do kategorii mierzalnych wyników procesu gromadzenia dochodów podatkowych. Pojęciem przeciwnym temu terminowi jest tzw. „luka podatkowa”, która jest miarą „nieszczelności” w systemie podatkowym. W wariancie arytmetycznym jest to różnica między podatkiem teoretycznie należnym (teoretyczne dochody budżetu państwa) a podatkiem faktycznie pobranym (rzeczywiste wpływy) ${ }^{6}$.

Według szacunków firmy doradczej $\mathrm{PwC}^{7}$, luka podatkowa w podatku od towarów i usług w Polsce, dzięki zastosowaniu nowych rozwiązań jej przeciwdziałania, mogła zmniejszyć się z poziomu 2,9\% PKB (52 mld zł) w roku 2016 do poziomu 2\% PKB (39 mld zł) w roku 2017 (rys. 3), czyli była o 13 mld zł mniejsza niż w roku poprzednim.

Działania w zakresie uszczelniania systemu podatkowego są podejmowane od ponad dziesięciu lat. W październiku 2013 r. zaczął obowiązywać odwrócony VAT na stal, elektronikę i metale szlachetne Przedtem handel tymi wyrobami był przedmiotem sporych nadużyć, szkodzących nie tylko budżetowi, ale i krajowym hutom stali. Ministerstwo Finansów w raporcie

${ }^{5}$ A. Pyszka, Istota efektywności. Definicje i wymiary, „Studia Ekonomiczne. Zeszyty Naukowe Uniwersytetu Ekonomicznego w Katowicach” 2015, nr 230, s. 15.

${ }^{6}$ Uzasadnienie do rządowego projektu z dnia 28 października 2016 r. ustawy o zmianie ustawy o podatku od towarów i usług oraz niektórych innych ustaw, RPU VIII, poz. 965.

7 https://www.pwc.pl/pl/media/2017/2017-10-19-pwc-luka-vat-2017.html [dostęp: 1.03.2018]. 
z marca 2016 r. przyznało, że ten środek pozwolił ograniczyć straty budżetu państwa o $424 \mathrm{mln}$ zł rocznie.

Intensyfikację obserwujemy systematycznie od 2015 r. Działania te - proste od strony operacyjnej i organizacyjnej - dotyczyły sfer, które budziły najwięcej wątpliwości oraz społecznego zaniepokojenia, takich jak np. kwestia oszustw podatkowych w obszarze paliw. W kolejnym etapie skupiono się na zmianie struktury administracji skarbowej, której efektem jest utworzenie Krajowej Administracji Skarbowej.

Zwiększenie skuteczności poboru podatku od towarów i usług wymagało nasilenia działań analitycznych aparatu skarbowego, zwiększenia jego zdolności modelowania, prognozowania i typowania zjawisk obrotu gospodarczego, których ujemne skutki oddziałują na efektywność systemu podatkowego.

W tym celu podjął ustawodawca działania zmierzające do powstania między innymi następujących zmian: wprowadzenia systemu wstępnej weryfikacji podatnika za pomocą Jednolitego Pliku Kontrolnego, wprowadzenia systemu teleinformatycznego STIR jak również mechanizmu podzielonej płatności - split payment.

\section{Odwrócony VAT w BUdownictwiE}

Założenia mechanizmu odwrotnego obciążenia są proste. Przy spełnieniu warunków wynikających z przepisów, usługa wykonana przez usługodawcę rozliczana jest podatkowo na poziomie usługobiorcy - inaczej zatem niż w „klasycznej” transakcji, za rozliczenie VAT należnego odpowiada nabywca usługi. W przypadku interesujących nas usług budowlanych najistotniejsze warunki są dwa. Po pierwsze, usługi świadczone muszą być przez usługodawcę działającego jako podwykonawca. Po drugie, usługi muszą pokrywać się z usługami wymienionymi w załączniku nr 14 do ustawy o PTU. Dodajmy przy tym, że schemat ten ma zastosowanie, gdy usługodawca (a więc podwykonawca) jest podatnikiem VAT nie korzystającym ze zwolnienia ze względu na obrót.

Łańcuch odwrotnego obciążenia obejmować może - w ramach jednego projektu budowlanego - całą grupę podwykonawców bliższych i dalszych. Podwykonawcą może być także zaangażowany przez inwestora (lub podwykonawcę) wykonawca zastępczy, jak również podatnik, który nabywa usługi budowlane i odprzedaje je (refakturuje) w niezmienionym kształcie podwykonawcy lub głównemu wykonawcy. 
Zakres usług objętych obowiązkiem odwrotnego obciążenia wskazany został poprzez zawartą w nowym załączniku do ustawy o PTU listę usług identyfikowanych poprzez PKWiU.

Powstaje pytanie, czy można zabezpieczyć tego rodzaju transakcję $\mathrm{w}$ drodze interpretacji indywidualnej. Istotnym elementem oceny prawnej stanowi bowiem klasyfikacja usługi na gruncie PKWiU, natomiast organy wydające interpretacje indywidualne odmawiają odpowiedzi na pytanie o klasyfikację, przerzucając ciężar w tym zakresie na wnioskodawcę. Pojawiają się jednak orzeczenia sądów administracyjnych, które próbują ten trend odwrócićs

Problem praktyczny dotyczyć może sytuacji, w której usłudze budowlanej towarzyszy inna czynność opodatkowana (usługa lub dostawa towarów) niebędąca usługą budowlaną, również świadczona przez podwykonawcę. Może być to np. usługa transportowa, usługa obróbki materiałów budowlanych, sprzedaż tych materiałów itp. Jeżeli czynność „dodatkowa” stanowi element kompleksowej usługi budowlanej, powinna zostać rozliczona na zasadzie odwrotnego obciążenia. Tymczasem kwestia kwalifikacji danego zespołu czynności jako świadczenia kompleksowego od lat sprawia problemy - jest to bowiem domena nie tyle przepisów, ale raczej praktyki orzeczniczej TSUE i sądów administracyjnych.

Pojęcie świadczenia kompleksowego jest określeniem pozaustawowym, do którego odnosił się Trybunał Sprawiedliwości UE m.in. w wyrokach z dnia 25 lutego 1999 r. w sprawie C-349/96, z dnia 27 października 2005 r. w sprawie C-41/04, z dnia z 11 czerwca 2009 r. w sprawie C-572/07 oraz z dnia 27 września 2012 r. w sprawie C-392/11 ${ }^{9}$. W ostatnim z powołanych orzeczeń Trybunał wskazał na takie kryteria uznania kilku świadczeń za jedno świadczenie, jak: występowanie tak ścisłego związku między co najmniej dwoma elementami albo czynnościami, że obiektywnie tworzą jedną całość oraz występowanie świadczenia głównego i świadczeń dodatkowych. Dodatkowym świadczeniem, traktowanym jak świadczenie główne jest takie świadczenie, które nie stanowi dla odbiorcy celu samego w sobie, lecz służy skorzystaniu w jak najlepszy sposób ze świadczenia

${ }^{8}$ Wyrok WSA w Krakowie z 10 września 2015 r., sygn. I SA/Kr 1206/15; wyrok WSA w Opolu z 24 sierpnia 2016 r., sygn. I SA/Op 185/16, Centralna Baza Orzecznictwa Sądów Administracyjnych CBOSA.

${ }^{9}$ Wyrok TSUE z dnia 25 lutego 1999 r. w sprawie C-349/96, z dnia 27 października 2005 r. w sprawie C-41/04, z dnia z 11 czerwca 2009 r. w sprawie C-572/07, LEX/el 2010 oraz z dnia 27 września 2012 r. w sprawie C-392/11, LEX/el 2012. 
głównego. Trybunał stwierdził, że zasadą jest, iż każde świadczenie dla celów opodatkowania podatkiem od towarów i usług powinno być traktowane jako odrębne i niezależne, jednak w sytuacji, gdy jedna usługa obejmuje z ekonomicznego punktu widzenia kilka świadczeń, usługa ta nie powinna być sztucznie dzielona dla celów podatkowych. Zatem, z ekonomicznego punktu widzenia, usługi nie powinny być dzielone dla celów podatkowych wówczas, gdy tworzyć będą jedną usługę kompleksową, obejmującą kilka świadczeń pomocniczych. Jeżeli jednak w skład świadczonej usługi wchodzić będą czynności, które nie służą wyłącznie wykonaniu czynności głównej, zasadniczej, lecz mogą mieć również charakter samoistny, to wówczas nie ma podstaw do traktowania ich jako elementu usługi kompleksowej.

Należy przede wszystkim przypomnieć, że na podstawie systemu odwrotnego obciążenia nie dochodzi w ogóle do zapłaty podatku od wartości dodanej między usługodawcą a usługobiorcą, gdyż ten ostatni w ramach dokonanych transakcji jest zobowiązany z tytułu naliczonego podatku od wartości dodanej i może jednocześnie, co do zasady, odliczyć ten podatek w taki sposób, że żadna kwota nie jest należna organom podatkowym ${ }^{10}$.

Należy również podkreślić, po pierwsze, że prawo do odliczenia stanowi integralną część mechanizmu podatku od wartości dodanej i co do zasady nie może być ograniczane ${ }^{11}$. Istnienie obowiązku odwrotnego obciążenia wyłącza możliwość odliczenia podatku z faktury błędnie wystawionej przez usługodawcę z pominięciem tego obowiązku (a więc z wykazanym podatkiem należnym). W tym przypadku istnieje bowiem wyraźna przeszkoda do odliczenia wynikająca z art. 88 ust. 3a pkt 7 ustawy o PTU. W sytuacji zafakturowania przez podwykonawcę dodatkowych świadczeń na ogólnych zasadach nabywca nie będzie zwolniony z obowiązku rozliczenia podatku należnego $\mathrm{w}$ ramach mechanizmu odwrotnego obciążenia. Powstaje pytanie, czy jako podstawę opodatkowania powinien przyjąć kwotę brutto czy netto z faktury. W orzecznictwie pojawił się pogląd, zgodnie z którym winna być to kwota brutto - jako kwota, do której zapłaty zobowiązany jest nabywca (przynajmniej do momentu korekty faktury in minus przez usługodawcę) $)^{12}$.

${ }^{10}$ Wyrok TSUE z dnia 6 lutego 2014 r. w sprawie C-424/12 SC Fatorie SRL v. Direcţia Generală a Finanţelor Publice Bihor, LEX nr 1421776.

11 Wyrok w sprawie Bockemühl, pkt 38; a także wyrok z dnia 15 lipca 2010 r. w sprawie C-368/09 Pannon Gép Centrum, Zb. Orz. s. I-7467, pkt 37 i przytoczone tam orzecznictwo.

${ }^{12}$ Wyrok WSA w Gliwicach z 26 stycznia 2015 r., sygn. III SA/Gl 936/14. 
Należy w tym miejscu przywołać pogląd zawarty w wyroku TSUE, według którego w ramach transakcji objętej systemem odwrotnego obciążenia Dyrektywa 112 oraz zasada neutralności podatkowej nie sprzeciwiają się sytuacji, w której usługobiorca zostaje pozbawiony prawa do odliczenia podatku od wartości dodanej, który nienależnie zapłacił usługodawcy na podstawie błędnie sporządzonej faktury również wówczas, gdy korekta tego błędu jest niemożliwa ${ }^{13}$.

Odwrotne obciążenie ma mieć charakter wyjątku, odstępstwa od ogólnej zasady funkcjonowania systemu VAT. Wprowadzenie odwrotnego obciążenia we wszystkich transakcjach, jeśli byłoby możliwe, zmieniłoby charakter VAT z podatku od wartości dodanej na podatek od sprzedaży do końcowego nabywcy. Niezależnie od zasadności tego pomysłu brak w Unii Europejskiej woli politycznej, by wprowadzić ogólnie obowiązujący mechanizm odwrotnego obciążenia ${ }^{14}$.

\section{Jednolity Plik Kontrolny (JPK)}

JPK został wprowadzony do polskiego porządku prawnego ustawą o zmianie ustawy Ordynacja podatkowa i innych ustaw z dnia 10 września 2015 r. $^{15}$.

Instytucja Jednolitego Pliku Kontrolnego została wprowadzona w art. 193a ustawy Ordynacja podatkowa ${ }^{16}$ znajdującym się w rozdziale 11 „Dowody”. $\mathrm{W}$ art. $180 \$ 1$ OP ustawodawca wskazuje, że „jako dowód należy dopuścić wszystko, co może przyczynić się do wyjaśnienia sprawy, a nie jest sprzeczne z prawem". Środki dowodowe mogą być klasyfikowane na podstawie różnych kryteriów. Najbardziej rozpowszechniony jest podział na nazwane i nienazwane środki dowodowe. Nazwanymi środkami dowodowymi są takie, które wprost wymienione są w OP, nienazwane zaś to pozostałe dowody, które mogą przyczynić się do wyjaśnienia sprawy, a nie są sprzeczne z prawem ${ }^{17}$.

${ }^{13}$ Wyrok TSUE z dnia 6 lutego 2014 r. w sprawie C-424/12 SC Fatorie SRL v. Directia Generala a Finantelor Publice Bihor (orzeczenie wstępne), LEX nr 1421776.

${ }^{14}$ House of Lords (2006-2007), Stopping the Carousel: Missing Trader Fraud in the EU, European Union Committee, Report of Session.

${ }^{15}$ Ustawa z dnia 10 września 2015 r., o zmianie ustawy Ordynacja podatkowa i innych ustaw, Dz.U. z 2016 r., poz. 1649.

${ }^{16}$ Ustawa z dnia 29 sierpnia 1997 r., Ordynacja podatkowa, Dz.U. z 2017 r., poz. 201, dalej jako OP.

${ }^{17}$ P. Pietrasz, Dział IV. Postępowanie podatkowe, [w:] C. Kosikowski, L. Etel (red.), Ordynacja Podatkowa, Warszawa 2013, s. 1088. 
W art. 181 OP znajduje się przykładowy katalog dowodów w postępowaniu podatkowym, wśród których wymienione są m.in. księgi podatkowe i informacje podatkowe. Wymienione w tym artykule dowody są kategoryzowane, jako dowody nazwane. Dowodami nienazwanymi są np. dokumenty prywatne.

Stosownie do postanowień $82 \S 1$ b ustawy Ordynacja podatkowa obowiązek przekazywania plików JPK_VAT, dotyczy osób prawnych, jednostek organizacyjnych niemających osobowości prawnej oraz osób fizycznych, prowadzących księgi podatkowe przy użyciu programów komputerowych. Realizacja tego obowiązku powinna nastąpić za pomocą środków komunikacji elektronicznej, w postaci elektronicznej odpowiadającej strukturze logicznej, o której mowa w art. 193a $\$ 2$ OP, na zasadach dotyczących przesyłania ksiąg podatkowych lub ich części określonych w przepisach wydanych na podstawie art. 193a $\$ 3$ OP, za okresy miesięczne w terminie do 25. dnia miesiąca następującego po każdym kolejnym miesiącu, wskazując miesiąc, którego ta informacja dotyczy.

Obowiązek złożenia comiesięcznego pliku JPK_VAT od 1 lipca 2016 r. dotyczy dużych przedsiębiorców, a od 1 stycznia 2017 r. obowiązkiem tym zostali również objęci mali i średni przedsiębiorcy. Natomiast mikroprzedsiębiorcy będą objęci tym obowiązkiem dopiero od 1 stycznia 2018 r. Przyporządkowanie poszczególnych podmiotów do wskazanych kategorii przedsiębiorców następuje zgodnie $\mathrm{z}$ art. 7 ustawy Prawo przedsiębiorcó ${ }^{18}$.

Obecnie obowiązuje siedem struktur logicznych w postaci schematu XML - JPK_VAT (Ewidencja Zakupów i Sprzedaży VAT), JPK_FA (Faktury), JPK_KR (Księgi Rachunkowe), JPK_WB (Wyciągi Bankowe), JPK_MAG (Magazyn), JPK_PKPiR (Podatkowa Księgowa Przychodów i Rozchodów) i JPK_EWP (Ewidencja Przychodów).

\section{MechanizM PODZIELONEJ PŁATNOŚCI (MPP) - SPLIT PAYMENT}

Mechanizm podzielonej płatności podatku od towarów i usług, tzw. split payment, zaczął obowiązywać od 1 lipca 2018 r. $^{19}$. Polega on na tym, że nabywca płacić będzie sprzedawcy tylko wartość netto zakupionego

${ }^{18}$ Ustawa z dnia 6 marca 2018 r., Prawo przedsiębiorców, Dz.U. z 2018 r., poz. 646. Ustawa w zakresie swojej regulacji wdraża dyrektywę 2006/123/WE Parlamentu Europejskiego i Rady z dnia 12 grudnia 2006 r., dotyczącą usług na rynku wewnętrznym, Dz.Urz. UE L 376 z 27 grudnia 2006 r., s. 36.

${ }^{19}$ Mechanizm został uregulowany w Rozdziale 1a ustawy o podatku od towarów i usług, dodanym przez art. 1 pkt 4 ustawy z dnia 15 grudnia 2017 r. o zmianie ustawy o podatku od towarów i usług oraz niektórych innych ustaw (Dz.U. z 2018 r., poz. 62 z późn. zm.). 
towaru lub usługi, natomiast kwotę podatku przekazywać będzie na specjalne konto - tzw. rachunek VAT. Kwoty zgromadzone na rachunku VAT będą stanowiły własność sprzedawcy, natomiast dysponowanie nimi będzie ograniczone w przepisach. Inicjatywę w zakresie stosowania mechanizmu split payment będzie miał podatnik będący nabywcą towaru lub usługi. Mechanizm ten będzie dobrowolny i znajdzie zastosowanie wyłącznie w odniesieniu do transakcji dokonywanych na rzecz innych podatników.

Nowelizacja ustawy o PTU, która wprowadza omawiany rodzaj płatności wymienia szereg przypadków, kiedy przedsiębiorca będzie mógł wykorzystać zgromadzone na rachunku VAT środki. Jedną z okoliczności jest wykorzystanie tych pieniędzy na poczet zaległości podatkowych. Ponadto podatnik będzie mógł regulować $\mathrm{z}$ tego rachunku kwotę zobowiązania podatkowego w VAT wobec urzędu skarbowego oraz będzie mógł swobodnie płacić kwotę VAT swoim dostawcom w ramach mechanizmu podzielonej płatności (art. 108a ustawy o PTU).

Na wniosek podatnika naczelnik urzędu skarbowego wydaje, w drodze postanowienia, zgodę na przekazanie środków z gromadzonych na wskazanym przez podatnika rachunku VAT na wskazany przez niego rachunek bankowy albo rachunek w spółdzielczej kasie oszczędnościowo-kredytowej, dla których jest prowadzony ten rachunek VAT.

Podzielona płatność jest zlecana przez podatnika w ramach jednego zlecenia płatniczego. Narzędziem (instrumentem) jej dokonania jest „komunikat przelewu”. Można określić go jako specjalną formatkę przelewu czy też druk przelewu, w ramach którego zlecający przelew będzie wskazywał dodatkowe jeszcze dane (informacje) dotyczące czy to wystawcy faktury, czy to samej faktury, które umożliwią bankowi (spółdzielczej kasie oszczędnościowo-kredytowej) podzielenie płatności na dwa strumienie pieniędzy i obciążenie oraz odpowiednio uznanie właściwymi kwotami rachunku rozliczeniowego oraz rachunku VAT ${ }^{20}$.

Nie sposób jednak nie odnotować pewnych niedogodności. Przede wszystkim, sama kwestia dobrowolności. Split payment w zaproponowanej formie sprawia, że to w gestii nabywcy leżeć będzie decyzja czy sprzedawca otrzyma do swojej tymczasowej dyspozycji kwotę w wysokości VAT. Nie ulega ponadto wątpliwości, że dla części podatników, MPP może spowodować pogorszenie płynności finansowej. Należy pamiętać, że w przypadku nagromadzenia się środków na rachunku VAT podatnik ma prawo do

${ }^{20}$ A. Bartosiewicz, VAT. Komentarz, wydanie XII, Warszawa 2018. 
wystąpienia $\mathrm{z}$ wnioskiem do naczelnika urzędu skarbowego o przekazanie tych środków na jego rachunek rozliczeniowy. Przekazanie środków nastąpi $\mathrm{w}$ takim samym terminie jak podstawowy termin zwrotu różnicy podatku VAT, tj. 60 dni. Jednakże jest to termin maksymalny i podatnicy będą mogli otrzymywać środki z rachunku VAT na rachunek rozliczeniowy również w terminie wcześniejszym, o ile przeprowadzona weryfikacja przez właściwego naczelnika urzędu skarbowego nie stwierdzi wystąpienia przesłanek uniemożliwiających wydanie zgody.

Mechanizm podzielonej płatności będzie oddziaływał na płynność finansową podatników w różnym stopniu i w różny sposób. To znaczy istnieje grupa podatników, którym MPP płynność finansową w jakimś zakresie pogorszy, istnieje również grupa podatników, dla których rozwiązanie to pozostanie bez wpływu na płynność finansową, a niektórym podatnikom wręcz ją poprawi, z uwagi na możliwość uzyskania zwrotu nadwyżki VAT naliczonego na rachunek VAT w terminie 25 dni. To, w jaki sposób MPP będzie oddziaływało na płynność finansową zależy od wielu czynników, w tym od struktury dokonywanych transakcji, stawek VAT przy zakupach oraz sprzedaży, struktury płatności, sposobów dokonywania płatności, rodzajów kontrahentów, czy wreszcie stosowania zwolnienia z PTU, np. $\mathrm{z}$ uwagi na poziom obrotów ${ }^{21}$.

Wśród zalet mechanizmu split payment wymieniany jest m.in. brak konieczności weryfikowania wiarygodności dostawców przez przedsiębiorców. Wystarczy upewnić się, że pieniądze zgromadzone na specjalnym koncie mają odzwierciedlenie w fakturach. Zdaniem ekspertów, split payment może być skutecznym narzędziem w przeciwdziałaniu nadużyciom podatkowym, choć niesie ze sobą także zagrożenia dla uczciwych przedsiębiorców.

Przyjęty przez rząd wniosek do KE o derogację (uchylenie obowiązywania) dla Polski - na podstawie art. 395 dyrektywy Rady 2006/112/WE w sprawie wspólnego systemu podatku od wartości dodanej - ma umożliwić naszemu krajowi ewentualne zastosowanie obligatoryjnego mechanizmu podzielonej płatności w PTU.

Obowiązek rozliczania VAT tą metodą dotyczyłby wówczas jedynie transakcji objętych obecnie mechanizmem odwrotnego obciążenia oraz odpowiedzialnością solidarną, tj. tych branż, w których zidentyfikowano istotne oszustwa w PTU.

${ }^{21}$ Pismo z dnia 31 stycznia 2018 r., Ministerstwo Finansów, Podsekretarz Stanu, PT8.054.8.2018. 
Akceptacja wniosku przez Komisję Europejską a następnie Radę Unii Europejskiej umożliwiłaby Polsce ewentualne skorzystanie z przewidzianego w nim rozwiązania już w 2019 r. Decyzje w sprawie terminu wdrożenia i zakresu obowiązywania obligatoryjnego mechanizmu podzielonej płatności będą podejmowane po analizie funkcjonowania fakultatywnego MPP.

\section{System Teleinformatyczny Izby Rozliczeniowej - STIR}

13 stycznia 2018 r. weszła w życie ustawa z dnia 24 listopada 2017 r. tzw. ustawa STIR 22 .

Najważniejszym celem ustawy STIR jest ograniczenie luki w podatku od towarów i usług. Luka ta jest spowodowana wyłudzeniami skarbowymi dokonywanymi najczęściej przez zorganizowane grupy przestępcze. Następuje to poprzez generowanie sztucznych tzw. transakcji karuzelowych za pomocą transferów pieniężnych na rachunkach bankowych. Faktycznym celem tych transakcji jest wyłudzenie podatku w postaci nienależnego zwrotu VAT, co powoduje znaczne straty Skarbu Państwa.

Dodany do ordynacji podatkowej dział IIIb został zatytułowany „Przeciwdziałanie wykorzystaniu sektora finansowego do wyłudzeń skarbowych”.

Artykuł 119zn przewiduje, że szef Krajowej Administracji Skarbowej (KAS) będzie analizował ryzyko wykorzystywania działalności banków lub spółdzielczych kas oszczędnościowo-kredytowych do popełniania przestępstw oraz przestępstw skarbowych. Dotyczy to przestępstw związanych z wyłudzeniami VAT, w tym także polegających np. na wystawianiu pustych faktur.

Analiza ryzyka ma być dokonywana przy uwzględnieniu wskaźnika ryzyka ustalanego przez izbę rozliczeniową w jej systemie teleinformatycznym, zwanym STIR.

${ }^{22}$ Ustawa z dnia 24 listopada 2017 r. o zmianie niektórych ustaw w celu przeciwdziałania wykorzystywaniu sektora finansowego do wyłudzeń skarbowych (Dz.U., poz. 2491). Niniejsza ustawa zmieniała następujące ustawy: ustawę z dnia 13 października 1995 r. o zasadach ewidencji i identyfikacji podatników i płatników, ustawę z dnia 29 sierpnia 1997 r. - Ordynacja podatkowa, ustawę z dnia 29 sierpnia 1997 r. - Prawo bankowe, ustawę z dnia 16 listopada 2000 r. o przeciwdziałaniu praniu pieniędzy oraz finansowaniu terroryzmu, ustawę z dnia 11 marca 2004 r. o podatku od towarów i usług, ustawę z dnia 5 listopada 2009 r. o spółdzielczych kasach oszczędnościowo - kredytowych, ustawę z dnia 16 listopada 2016 r. o Krajowej Administracji Skarbowej. 
Ordynacja przewiduje m.in: automatyczne ustalanie w STIR wskaźnika ryzyka wykorzystywania banków i spółdzielczych kas oszczędnościowo-kredytowych do popełniania wyłudzeń skarbowych. STIR będzie analizował dane z banków i SKOK-ów oraz dane publicznie dostępne, przekazane z Centralnego Rejestru Podmiotów - Krajowej Ewidencji Podatników (CRP KEP). Na banki i SKOK-i zostanie nałożony obowiązek przekazywania do STIR niektórych danych, w tym stanowiących tajemnicę bankową lub tajemnicę zawodową SKOK - w celu ustalenia wskaźnika ryzyka. Izba rozliczeniowa będzie przekazywać informacje o wskaźniku ryzyka szefowi KAS oraz bankom i SKOK-om.

Zadania KAS zostaną poszerzone o rozpoznawanie, wykrywanie i zwalczanie przestępstw związanych z tzw. „praniem brudnych pieniędzy”.

Dane przekazywane do STIR będą dotyczyły rachunków przedsiębiorców niezależnie od tego, czy są oni podatnikami VAT. W razie uzyskania informacji, że dany podmiot może prowadzić działania zmierzające do wykorzystania działalności banków lub SKOK-ów do celów mających związek z wyłudzeniami skarbowymi, naczelnik urzędu skarbowego będzie miał możliwość odmowy jego rejestracji jako podatnika VAT ${ }^{23}$.

Niezwłoczna analiza ryzyka Szefa KAS przy pomocy nowoczesnych narzędzi informatycznych umożliwi szybką reakcję organów KAS. Przewidziana przez ustawę STIR blokada rachunku podmiotu kwalifikowanego zapobiegnie transferom środków pochodzącym z wyłudzeń. Blokada rachunku będzie możliwa na 72 godziny z opcją przedłużenia o trzy miesiące, po spełnieniu ściśle określonych warunków. Powyższe nie dotyczy rachunków bankowych osób fizycznych, służących do ich prywatnych rozliczeń. Dokładna i kompleksowa analiza pozwoli ponadto na zminimalizowanie ryzyka niechcianych konsekwencji dla uczciwych przedsiębiorców.

Efektem prewencyjnego oddziaływania wprowadzanego systemu analizy ryzyka i możliwości szybkiej reakcji organów skarbowych powinno być istotne ograniczenie wyłudzeń skarbowych, poprawa warunków prowadzenia działalności gospodarczej dla wszystkich podatników poprzez przywrócenie uczciwej konkurencji na rynku oraz umocnienie pewności prawa w wyniku upublicznienia informacji o zarejestrowanych i wykreślonych podatnikach VAT ${ }^{24}$.

${ }^{23}$ L. Etel (red.), Ordynacja podatkowa. Komentarz aktualizowany, Lex/el. [dostęp: 20.06.2018].

${ }^{24}$ Uzasadnienie do projektu z dnia 12 października 2017 r. ustawy o zmianie ustaw w celu przeciwdziałania wykorzystaniu sektora finansowego do wyłudzeń skarbowych, Druk sejmowy Nr 1880. 
Ordynacja podatkowa w art. 119zp zobowiązuje banki do przekazywania KIR wszystkich danych pozwalających na identyfikację przedsiębiorcy: adresu, regonu i numerów rachunków oraz powiadomienia nie później niż w ciągu 24 godzin o wszelkich zmianach, otwartych lub zamkniętych kontach. Pełny zakres danych umożliwiających działanie STIR określi w rozporządzeniu Minister Finansów.

Wszystkie transakcje we wszystkich systemach płatniczych będą podlegały zatem codziennemu raportowaniu ze strony banków. Przetworzenie danych polega na wykorzystaniu odpowiedniego algorytmu, którego sposób tworzenia był ściśle przemyślany i doprecyzowany i jak dotychczas nie ujawniony. Ministerstwo Finansów zapewnia, że narzędzie, którego podlega kalibracji będzie działać niezwykle precyzyjnie i wykrywać wyłącznie podatników kradnących VAT i tylko takim podatnikom będą blokowane konta. Pozostaje mieć wiarę w nieomylność stworzonego systemu.

\section{6. „USZCZELNIANIE” ZA POMOCĄ USTAW NIEPODATKOWYCH}

Mechanizm uszczelniania systemu podatkowego widoczny jest również przy zastosowaniu ustaw niepodatkowych a przecież jedną z rudymentarnych zasad systemu podatkowego w Polsce jest zasada wyłączności oraz zupełności ustawy w zakresie kształtowania elementów konstrukcji prawnej podatku. Wyłączność ustawy w prawie podatkowym ma bowiem duże znaczenie nie tylko dla stanowienia i stosowania prawa, ale też dla ochrony jednostki przed dowolnością, czy uznaniowością w określaniu ciążących na niej obowiązków podatkowych. Zasada wyłączności oraz zupełności ustawy wynika $z$ treści przepisu art. 217 Konstytucji RP ${ }^{25}$, zgodnie z którym nakładanie podatków, innych danin publicznych, określanie podmiotów, przedmiotów opodatkowania i stawek podatkowych, a także zasad przyznawania ulg i umorzeń oraz kategorii podmiotów zwolnionych od podatków następuje w drodze ustawy. za niedopuszczalną ingerencję prawną w sferę konstrukcji prawnej podatku od towarów i usług należałoby uznać zaproponowaną w ustawie o zmianie ustawy o biokomponentach i biopaliwach ciekłych oraz niektórych innych ustaw ${ }^{26}$ propozycję dodania

25 Ustawa z dnia 2 kwietnia 1997 r., Konstytucja Rzeczypospolitej Polskiej, Dz.U. z 1997 r. Nr 7, poz. 16.

${ }^{26}$ Ustawa z dnia 24 listopada 2017 r., o zmianie ustawy o biokomponentach i biopaliwach ciekłych oraz niektórych innych ustaw, Dz.U. z 2017 r., poz. 2290. 
przepisu art. 11a w brzmieniu: „Zabrania się wytwórcom wykorzystywania biomasy będącej produktem działów przemysłu powiązanych z rolnictwem, przy dostawie której została zastosowana stawka podatku od towarów i usług wyższa niż 5\%, do wytwarzania estrów".

Rozumiejąc i zgadzając się, oczywiście, z dążeniem organów władzy publicznej do uszczelniania systemu podatkowego i tym samym rozumiejąc intencję związaną z propozycją wprowadzenia zacytowanego przepisu, należy jednak odnieść się do tego rozwiązania niezwykle krytycznie. Prowadzi ono bowiem de facto (choć nie wprost, tj. nie w sensie jurydycznym, a niejako „kuchennymi drzwiami”) do zmiany stawki podatkowej w zakresie opodatkowania dostawy biomasy służącej do wytwarzania estrów. Oczywiście, biorąc pod uwagę proponowaną treść przepisu art. 11a, nie można twierdzić wprost, iż ustawodawca wprowadza tym przepisem zmianę stawki podatkowej poprzez obniżenie stawki w VAT na towary, które do tej pory były opodatkowane stawką podstawową. Niemniej jednak przy uwzględnieniu realiów rynkowych obowiązujących w branży obrotu biopaliwami, zakaz zawarty w propozycji przepisu art. 11a przesądza o tym, iż albo:

a) ten sam towar w rozumieniu ustawy o PTU, bez zmiany właściwości fizykalno-chemicznych, będzie traktowany jako towar opodatkowany stawką preferencyjną, choć biorąc pod uwagę rozwiązania konstrukcyjne w ustawie o PTU (a także, o czym poniżej, w Dyrektywie 2006/112), ze względu na to, iż nie może być przeznaczony do celów spożywczych powinien być opodatkowany stawką podstawową,

b) albo podatnicy z branży obrotu biopaliwami będą musieli wykorzystywać do produkcji estrów wyłącznie olej stricte jadalny, tj. taki który $\mathrm{w}$ istocie do tej pory (ze względu na spożywcze przeznaczenie) był opodatkowany stawką $5 \%$.

W obu opisanych przypadkach zachowanie podatnika będzie wiązało się z podjęciem ryzyka. W przypadku zastosowania stawki 5\%, bez zmiany w ustawie podatkowej, na towar, który nie zmienił właściwości fizykochemicznych, podatnik może narazić się na zarzut stosowania niewłaściwej, zawyżonej stawki (23\%) na dostawy oleju przed dniem 1 stycznia 2018 r. Niezastosowanie zaś stawki 5\%, czyli stosowanie zgodnie z przepisami o VAT stawki 23\% na olej, który de facto nie jest jadalny (zgodnie z poz. 20 załącznika nr 10 do ustawy o PTU stawka obniżona ma zastosowanie tylko do oleju jadalnego) eliminuje wprawdzie ryzyko ewentualnych zarzutów ze strony organów podatkowych o stosowaniu niewłaściwej stawki w latach 
poprzedzających rok 2018, niemniej jednak nie pozwoli podatnikom na zaliczenie takich dostaw do Narodowego Celu Wskaźnikowego (NCW) ${ }^{27}$, a w następstwie narazi na konsekwencje wynikające z przepisów ustawy o biokomponentach i biopaliwach ciekłych.

Ponadto wskazać należy, iż podatnik w zakresie stosowania właściwej stawki podatkowej związany jest przepisami ustaw podatkowych, a elementy konstrukcyjne podatku nie mogą być zmieniane innymi ustawami, zwłaszcza ustawami spoza systemu prawa podatkowego.

\section{Podsumowanie}

W polskim systemie prawa podatkowego funkcjonuje 1,5 miliona stron przepisów i interpretacji związanych z PTU.

Wszystkie dane są trudne do zweryfikowania z istoty szarej strefy, której zweryfikować nie można. Podatek od wartości dodanej, który ma być neutralny dla przedsiębiorcy z uwagi na swoją konstrukcję, z jednej strony prowokuje i będzie prowokował do wyłudzeń, z drugiej zaś walka z tymi wyłudzeniami zaczyna sprowadzać istotę VAT wraz z jego neutralnością dla przedsiębiorcy do czegoś, co można by uznać za zbędne. Jak długo podatek od wartości dodanej będzie funkcjonować w systemie prawnym, tak długo będziemy walczyć $\mathrm{z}$ wyłudzeniami i oby nie doprowadziło to do całkowitego zapomnienia, czym dla przedsiębiorcy ze swoją neutralnością miał być VAT.

\section{BIBLIOGRAFIA}

Bartosiewicz A., VAT. Komentarz, wydanie XII, Warszawa 2018.

Etel L. (red.), Ordynacja podatkowa. Komentarz aktualizowany, Lex/el., [dostęp: 20.06.2018]. Pietrasz P., Dział IV. Postępowanie podatkowe, [w:] C. Kosikowski, L. Etel (red.), Ordynacja podatkowa, Warszawa 2013.

Pyszka A., Istota efektywności. Definicje i wymiary, „Studia Ekonomiczne. Zeszyty Naukowe Uniwersytetu Ekonomicznego w Katowicach" 2015, nr 230. https://www.pwc.pl/pl/media/2017/2017-10-19-pwc-luka-vat-2017.html [dostęp: 1.03.2018].

${ }^{27}$ Stosownie do art. 2 ust. 1 pkt 24 ustawy z dnia 25 sierpnia 2006 r., o biokomponentach i biopaliwach ciekłych, Dz.U. z 2014 r., poz. 1643 ze zm., przez Narodowy Cel Wskaźnikowy rozumie się „minimalny udział biokomponentów i innych paliw odnawialnych zużytych we wszystkich rodzajach transportu w ogólnej ilości paliw ciekłych i biopaliw ciekłych zużywanych w ciągu roku kalendarzowego w transporcie drogowym i kolejowym, liczony według wartości opałowej. 
Summary. The paper therefore explores the analysis of selected changes which have been implemented and which are commonly referred to as "the tightening of the tax system." This is the reaction to those behaviors within legal and commercial exchanges which could be classified as a misuse of the tax system. The paper collates the most important, in the author's opinion, possible legal responses to exchange situations having as their consequence an impairment or threat to the financial interest of the state, including, in particular, the phenomenon for which the standard term in criminal law dogma is the tax loss. In the paper, possible methods of countering tax losses in the tax system will be addressed, while identifying mechanisms which are relevant for the legal construction and specificities of the tax on goods and services. The existing legal regulations are not sufficient for preventing fiscal fraud; the structure of the tax itself and the rules on setting the tax rates are the source of the threats encountered, while the expectations placed upon the valued added tax by the EU and the Member States are not met.

Keywords: value added tax, split payment, STIR, Standard Audit File, VAT account, reverse charge of VAT, "sealing" the tax system, "tax gap" 